\title{
PISKÓTI István
}

\section{A BUSINESS MARKETING IDENTITÁSA - ELMELETI, KUTATÁSI TRENDEK, AZ INNOVÁCIÓVEZÉRELT MODELL}

A business marketing mint a marketingtudomány jellegzetes alkalmazási területe határozott szakmai, elméleti fejlódési utat járt be az elmúlt évtizedekben. Jelen tanulmány - a tudományos identitás jegyeit keresve - felvillantja az industrial, a business marketing történetének fó állomásait, diszciplináris alapjait, a meghatározó elméleti megközelítéseket és az aktuális kutatási kérdéseket, trendeket. A tanulmány második része, az egyik meghatározó kutatási kérdést, az innovációorientáltságot vizsgálja. Az elméleti modellek és a szerző többéves, saját kutatási programjának eredményei megerősítik, hogy a business piacokon is az összehangolt, innovációportfólióra épülő - ,innovációs versenyelőnyök” határozzák meg a vállalkozások sikerét, melyet hatékony marketingképességek és -tevékenységek kell, hogy támogassanak.

\section{Kulcsszavak: business marketing, innovációportfólió, marketingképességek}

A marketingkutatók, így a business marketingesek is, a különböző elméleti megközelítéseket, a társtudományokat ötvözik, melyek az adott, önállósodó tudomány sajátos fejlődési útvonalát rajzolják fel. A business marketing tudományos alapjait leginkább a szervezetelmélet, a rendszerelemzés, a közgazdaságtan, a pszichológia, a szociológia, az antropológia képezi. A tanulmány első részében azt vizsgáljuk, hogy a marketingen belül mennyire bír önálló tudományos identitással a business marketing, milyen szakmai, módszertani sajátosságokban jelenik meg a szervezetek piacának marketingje.

\section{A business marketintg tudományterületi identitása}

Azt a szakmai nézetet osztom, hogy a marketing általános elmélete, mint közös "identitásmag" mellett, részdiszciplínaként a business marketing önálló tudományos, kutatási karakterrel bír, a fogyasztói piaci, a fogyasztásicikk-marketingtől megkülönböztethetően, de egymást megtermékenyítő módon fejlődik. Az európai marketingtudomány fejlődésében Hansen - Bode (2006, idézi Meffert, 2007) az alábbi fejlődési szakaszokat különbözteti meg:

1. Vállalatirányítás marketingorientáltan (1950-es és korai 60-as évek)

A termékalapú és intézményi szemléletmódban - az angolszász mintákra épülöen - eröteljesen a neoklaszszikus értékesités-gazdaságtan jelent meg, a „homo oeconomicus" modellgondolkodással, az értékesitési eszközök optimalizálásával. Az integrált, piacorientált vállalatvezetési szemléletet a döntés- és magatartásorientált megközelitések hozták létre. Ekkor épült fel a fogyasztási cikk területéról kiinduló egységes, generalista marketingtudomány.

2. A marketing továbbfejlesztése társadalmi perspektívával (késő 1960-es és a 70-es évek)

A társadalmi szükségletek oldaláról érkezö kritika, a fogyasztási, a környezeti problémák módosításra késztették az uralkodó marketingfilozófiát. A marketing kiszélesitésére, mélyítésére irányuló ún. broedening és deepening vita eredményezte a társadalmi felelósség és az etika piacorientált vezetésben való megjelenését, a nonprofit, társadalmi marketingkoncepciók révén. Másoldalról a stagnáló piacok, a versenystratégiák elótérbe keriulése (Porter 1983) volt az, mely zárójelbe tette a marketingtudomány generikus piacstratégiai megértését.

3. Fragmentáltság és a marketing konszolidálása (1980-as és 90-es évek)

Ebben az idôszakban jelentôs kihívások érték a marketingtudományt, s máig ható új megatrendek jelentek meg, mint a nemzetköziesedés, a globalizáció, az új gyártási és infokommunikációs technológiák, valamint a civil társadalom megerösödése. Ez az idószak a differenciálódás, specializálódás és a határok feloldódásával jellemezhetó. Megerösödtek a fogyasztási cikk szektoron túli terüle- 
tekre kiterjedő marketingelméletek és -koncepciók iránti igények, úgymint az industrial (business) marketing, a kereskedelmi marketing, a szolgáltatásmarketing, s a marketingkoncepciók más szervezeten belüli funkcionális területekre történó kihatásai, valamint a marketingen belüli speciális téma- és eszközterületek pl. internetmarketing, direktmarketing, eseménymarketing stb.

A 2000-es évek marketingje az integráltság, a kooperáció és a társadalmi felelősség elvének együttes érvényesülésének erősödéséhez, a holisztikus koncepció kiteljesedéséhez vezet (Kotler, 2008, 2012), mely a jövőben várhatóan integrálja majd a marketing profitmotivált és a társadalmi felelősségre épüló tudományos és gyakorlati fejlődési ágait (Piskóti, 2012). Az évtizedek alatt létrejött elméleti fragmentáltság megteremtette a marketing koncepcionális, szemléleti egységesitésére való törekvést is, melyet a különböző szemléletek közötti „,kommunikációs" korlátok nehezítenek. A marketingtudomány e közös modellekre, a marketing általános elméletének (general theory of marketing) megerósitésére irányuló törekvése (Hunt, 1983; Lusch - Vargo, 2006; Vargo - Lusch, 2011) mellett, ugyanakkor megjelentek az alkalmazási területek, mint résztudományterületek önálló identitásának sajátosságait összegző kutatások is. Az Industrial Marketing Management (IMM) folyóirat mintegy két éve különszámot szentelt az industrial (business) marketing elméleti fejlódésének, módszertani kereteinek áttekintésére (Peters et al., 2013). A tanulmányok célja az volt, hogy hozzájáruljanak a tudományterület sajátosságai, a business marketing eredetiségét, a tudományos identitását képezô összefüggések feltárásához.

Kiindulásként érdemes felidézni e tudományterület történeti fejlődésének néhány lépcsőfokát, mert ez az identitáselemek feltárása mellett segítheti a jelenlegi kutatási trendek értelmezését, a gyakorlati üzleti döntéseket jobban támogató marketingmodellek, -módszerek kidolgozását, melyekre a kutatóknak és a vállalkozásoknak egyaránt szükségük van.

A szervezetközi piac minden, a vállalkozások mellett, az állami, önkormányzati és nonprofit, civil szervezeti tranzakciókat, kapcsolatokat (B2G, B2S, S2B, G2B stb.) egyaránt átfogja. A business-to-business (B2B) eredetileg csak a profitmotiválta vállalkozások közötti cseréról, kapcsolatokról szól. Ha e kapcsolatokból kivesszük a végső fogyasztó felé értékesítő szervezetekkel, a kereskedőkkel való együttmúködéseket, visszajutunk a klasszikus industrial marketing, (Industriegütermarketing), hazai szóhasználatunkban korábban ipari marketingnek ismert terepekhez (Piskóti, 2014, p. 14.). Ha a business marketing kezdetét keressük, akkor akár több ezer évre is visszanyúlhatunk, ugyanakkor elméletének története relatíve rövid. Bár gondolatisága több, mint száz éve megjelent a közgazdasági írásokban, mégis jelentősebb számú szakmai marketingtanulmányok e téren csak az elmúlt négy évtizedben születtek, s talán most vagyunk a gyorsuló elméletfejlödés szakaszában (Möller, 2013). A szervezetek közötti ügyletek marketingvizsgálata szinte ugyanolyan régi, mint maga a marketingé, hiszen már a múlt század harmincas éveinek elején megjelentek az ,industrial marketing" írások (Melvin T. Copeland: Cases in Industrial Marketing (1930), John Hutchinson Frederick's: Industrial Marketing (1934)). Az industrial marketinget mindig is a marketing tradicionális elemének tekintették, mégis a marketingen belüli önálló (tudományos, kutatási) területként Zober 1971-es publikációja legitimálta. Ehhez az is jelentősen hozzájárult, hogy az ötvenes évek végétől a Harvard Business School egyetemi kurzusai is megjelentek a témában (Vargo - Lusch, 2011). A B2B elmélete az 1800 -as évek végétől is értelmezhetó, amikor John Wanamaker sikeres üzletember, 1899-ben a kereskedelemben elkezdte elemezni a fogyasztó, a kereskedő és a termeló szerepét, a szükségszerúen szoros kapcsolatukat, felvetve (az elégedettség- és profitnövelés területén) a kölcsönösség és a bizalom kérdését. Ezt követően a B2B-kutatás fejlődésében hosszú időszakon át „csend” volt, hiszen az elemzésekben az egyedi, gyakorlatalapú megközelítés, az üzletemberek viselkedésének vizsgálata került előtérbe. Az elmélet fejlődése akkor gyorsult fel, amikor az üzleti kapcsolatok a tudományos érdeklődés fókuszába kerültek (Sheth - Gardner - Garrett, 1988). A business marketing elméleti átalakulása a közgazdasági alapoktól a magatartás-tudományi építkezésig haladt, úgy hogy egyéb marketingalkalmazások irányába is mozdult. Wanamaker a marketing közgazdasági megalapozásának úttörője volt, implicit módon már megjelenítette a társadalmi, a magatartás-tudományi illeszkedés szükségességét, bár erre csak mintegy nyolcvan év után került sor, amikor a követői, a tranzakciós megközelítéstől a kapcsolati, interakciós, magatartási fókusz felé mozdultak. A business marketing elmúlt évtizedeiben számos elméleti iskola megjelenését találjuk, úgymint az intézményi közgazdaságtani, az információ-gazdaságtani, a piaci folyamatelméleti, a viselkedés-, magatartás-tudományi, a kapcsolati, hálózati perspektívát és az értékorientált megközelítést. Az elméletfejlődés különbözőképpen strukturálható. Sheth - Parvatiyar (1995) három szakaszt határoztak meg a piacfejlődésben, úgymint a preindusztriális, az indusztriális és a posztindusztriális. Wilkie - Moore (2003) a marketinggondolkodás öt szakaszát látja: premarketing (1900 előtt), alapozás (1900-1920), a területek formalizálása (1920-50), paradigmaváltás 1950-80, a váltás intenzifikálása (1980-tól). A marketing elsô korszakai lényegében a cseredomináns marketingkutatást jelentették 1980-ig, míg a posztindusztriális, a paradigmaváltás utáni szakaszok a magatartástudományi megközelítést. Az 1. ábrán látható, hogy a szakaszok mint egy evolúciós fejlödés jelennek meg, melyekben azért voltak viharos átmenetek is (Hadjikhani - LaPlaca, 2013). 
Közgazdasági és magatartás-tudományi alapok a B2B-ben, a marketingelmélet két fejlődési útvonalán

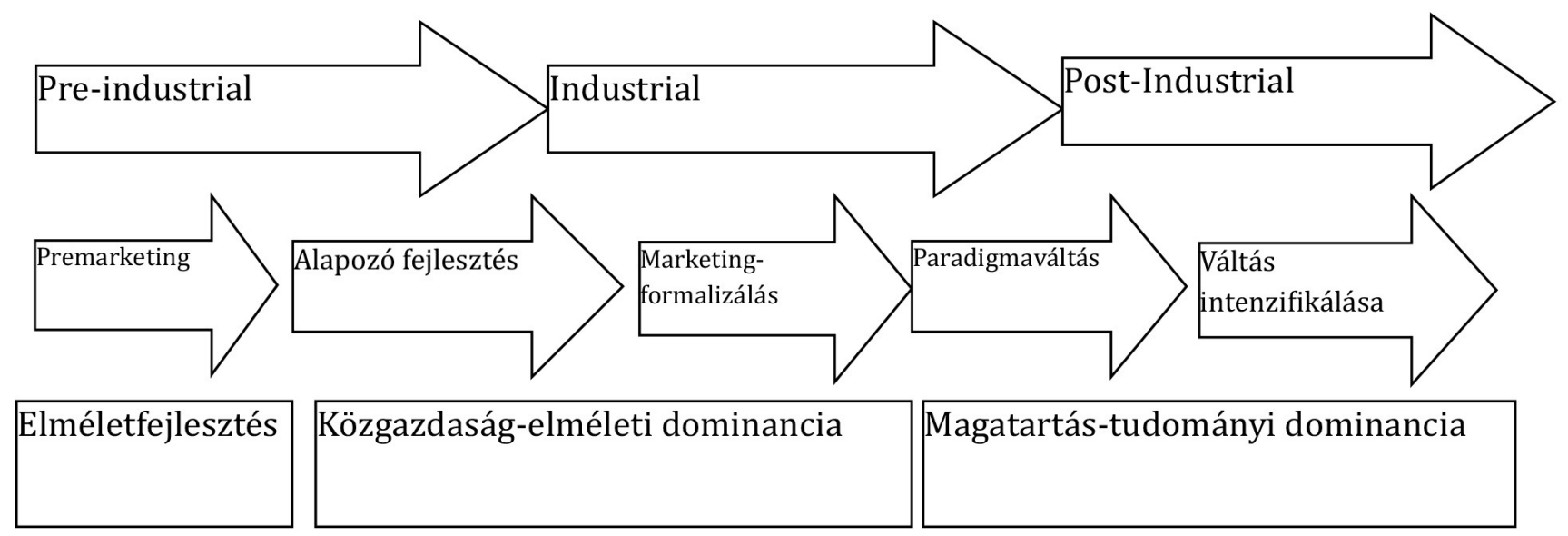

Forrás: (Hadjikhani - LaPlaca (2013, p. 295.) alapján

Az üzleti csere tranzakció- és kapcsolatalapú elméleti megalapozása

\begin{tabular}{|l|l|}
\hline tranzakció-alapú üzleti csere & kapcsolatalapú üzleti csere \\
\hline közgazdasági alap & magatartási alap \\
\hline gazdasági csere & gazdasági és társadalmi csere \\
\hline egyszerú eróforrás és információcsere & komplex erőforrás és információcsere \\
\hline racionalitás - magas az információkhoz hozzáférés & $\begin{array}{l}\text { korlátozott racionalitás - információhoz hozzáférés in- } \\
\text { komplett }\end{array}$ \\
\hline függetlenség & függóség \\
\hline néhány csere & nagyszámú cserekapcsolat \\
\hline profitmaximalizálás a cégeknek & kölcsönös előnyök a partnerek számára \\
\hline push stratégia -a cég dönt & közös stratégiafejlesztés \\
\hline eladók fölénye & egyenló, kooperatív pozíció \\
\hline konfliktus & kooperáció \\
\hline alacsony adaptáció & nagy adaptáció \\
\hline közép- vagy rövid távú időhorizont & közép- vagy hosszú távú időhorizont \\
\hline
\end{tabular}

Forrás: Hadjikhani-LaPlaca (2013, p. 296.) alapján

Hadjikhani - LaPlaca (2013) szerint a business marketing elméletének fejlődése a tranzakciós marketingtől a kapcsolati alapú marketingre (azok kontrasztjára) vezetődik át, melyek elkülönítését, paradigmaváltásként értelmezik. (1.táblázat)

A kapcsolati marketing, s annak irányai egyre inkább úgy túnik, hogy a business marketing domináns megközelítésévé válik (Möller, 2013). Kétségtelenül ezt erősíti a témában megjelenő publikációk száma, az a tény, hogy a kapcsolatok, hálózatok egyre nagyobb szerepet játszanak az új üzleti modellekben és talán a legfontosabb aspektus, hogy a kapcsolatok, interakciók, hálózati szereplők alapvetô pozícióval bírnak a SDL (Service-Dominant Logic)-ben, a közös értékalkotás (value-co-creation) megközelítésben, s a magját képezik az értékalapú marketingelméleti megközelítésnek (Gummesson - Mele, 2010; Lusch - Vargo, 2006). A kapcsolati marketingnek két alapvető - piacalapú és a 
hálózatalapú - iránya van (Möller - Halinen, 2000), melyek különbözó szemlélete, módszertana jelenik meg a kutatásokban. A piacok, mint hálózatok megközelítés egyre erőteljesebben bontakozik ki napjainkban, amikor a hagyományos ágazati keretek és gondolkodás „,szétesését”, ,nyitottságát” látjuk, amikor egyre inkább összefonódnak a vállalkozások gazdálkodási folyamatai a térségek versenyképességi kérdéseivel, a társadalmi ügyek megoldásával, az innovációs folyamatok egyre nyitottabbá válásával. Ugyanakkor meglepő módon - gyakran, talán éppen a gyakorlatorientáltság okán - tapinthatóan nem fektetnek a business marketing kutatói oly nagy figyelmet az ontológiai és episztemológiai megközelítések különbözőségére (Easton, 1998), hanem a businessmarketing-kutatások inkább a széles körú, gyakorlati, módszertani megközelítések és a kutatási tradíciók (kritikai realizmus, társadalmi konstruktivizmus, pozitivizmus) kontrasztjával jellemezhetők. A kapcsolati marketing elmélete, melynek forrásai között számos megközelítés fellelhető (úgymint szolgáltatásmarketing, interaktív marketing, üzleti hálózatok, csatornakapcsolatok stb.) mind a business. mind pedig a fogyasztói marketingre egyaránt kihat, ez oldalról is megteremtve az egységes megközelítés, mint a marketing általános elmélete (general theory) konstrukció lehetôségét (Lusch - Vargo, 2006; Vargo Lusch, 2011). Hunt (1983) tanulmányában a marketing általános elméletének, az általános érvényú elméletek fontosságáról ír. Véleménye szerint négy tényezó határozza meg egy elmélet általános érvényességét, azaz (1) több jelenséget magyaráz és jelez elöre, (2) különbözó koncepciókat integrál, rendszerez, kapcsol egybe, (3) teljesen magába foglalja a kevésbé általános elméleteket és/vagy (4) az absztrakció magas szintjét képviseli. $\mathrm{Az}$ 50-es, 60-as években kifejlesztett, a piaci folyamatokra, a differenciált előnyökre épülő funkcionális elméletek (Alderson, 1957, 1965), avagy a 90-es években Hunt - Morgan által leírt a versenyeróforrás-elönyök $(R-A)$ elmélete a marketing általános elméletéhez tartozónak tekinthetók. Hunt (2013) - az IMM különkiadásába írt - tanulmányában vázolja fel - az R-A-elmélet általános érvényességét, mint a business marketing általános elméletének részét, s ezáltal is megerósítve, hogy az erőforrás-elónyökön alapuló versenyelméletek a marketing általános elméletének alapját képezik. Elemzésében részletesen vizsgálja az R-A-elmélet viszonyát az aldersoni funkcionális elmélet mellett, az ISBM (Institute for Study of Business Markets) Value Delivery Framework és az IMP elméleti struktúrájához is. Az ISBM VDF szerint a business-to-business marketingmenedzsmentnek öt specifikus lépése van, úgymint (1) az (ügyfél) érték megértése (elvárások), (2) stratégia kialakitása (STP), (3) az ügyfélérték megalkotása (innováció), (4) az érték kommunikációja és disztribúci- ója, míg az (5) az életciklus-menedzsment (márkázás és ügyfélkapcsolatok). Hunt (2013) további elemzésében az IMP-iskolával való kapcsolódásokat annak négy alappremisszájára építi, nevezetesen (1) az eladó-vevó közötti kapcsolatok fontossága, mint az interakciók komplex pályája, (2) a tranzakcióban részt vevó személyek közötti interakciók vizsgálatának fontossága, (3) a piaci struktúra stabilitását az eladó és vevó magatartásának kölcsönös ismerete biztosítja, (4) a piacok megértését a kapcsolatok mindkét oldalának folyamatos elemzése biztosítja. Hunt szerint mind az IMP, mind az ISBM által kialakított megközelítéshez illeszkedően bizonyítható a R-A-elónyök elméletének érvényessége a business piacokon, $\mathrm{s}$ ez fontos lépés egy általános elmélet felé. Ezen eredményhez kapcsolódóan is, teendők vannak a business marketingben az inside-out és az outside-in elméleti megközelítések integrálására, ahol Saeed és társai (2013) az innováció, a vállalkozások eredményességének viszonyában igazolták együttes, közös hatásukat. A 2013-ban lefolytatott szakmai vita a business marketing önálló résztudományi identitását erösítette meg, megállapítva ugyanakkor, hogy számos teendő van a különböző ún. részelméletek, modellek (middle-range) integrálásában, mixelésében (Peters et al., 2013).

A business marketing tudományának megvannak az identitásépítő sajátosságai. Jelentős tudományos előzményei, elméleti sarokkövei vannak, gyakorlati fókuszú, nem jellemzik episztemológiai vagy ontológiai dominanciák, sokszínú módszertani megközelítések mozgatják a kutatásokat, s így egyre fontosabb szerepe van a marketing általános elméleti fejlódésében, amit a korábbi alulreprezentáltságához képest a vezetô folyóiratokbéli növekvő súlya, s azok citációs indexei is jeleznek. A business piacok tudományos, gyakorlati marketingjét meghatározó, leginkább kiemelt sajátosságai az alábbiak:

- korlátozott számú piaci szereplói kör jellemzi, mely gyakorta mono-, illetve oligopolisztikus piaci struktúrákat, helyzeteket eredményez,

- a business piacokon származtatott kereslettel találkozunk, hiszen a nyersanyagok, alkatrészek, félkésztermékek, gyártóberendezések keresletét az általuk, a belőlük létrehozandó „,végtermék”, a fogyasztási cikkek iránti kereslet alakulása mozgatja, s készteti a business marketingest kettős (két) piaci aktivitásra,

- különösen a beruházási javaknál, azok ciklikusságából eredően a keresleti folytonosság gyakori hiánya, idóbeni merevsége fontos marketingkihívás,

- a business piacokon többnyire nem egyszerúen terméket, hanem üzleti problémamegoldást (komplex termék- és szolgáltatáscsomagot) keresnek a vevók, 
- még meg nem született termékekre, „nemlétező megoldásokra" köttetnek a szerződések, melyek tárgya így az eladói kompetenciák, bizalom által megalapozásra kerülő „,́géret”,

- a business javak vásárlásának sikere jelentős mértékben hat ki a vevő üzleti sikerére, így a megbízhatóság, a kölcsönös függóség, a kölcsönös tanulás, az együttmúködés fontos kategóriává válik,

- felértékelődik a beszerzési folyamat, mint a problémadefiniálás, a megoldáskeresés és bizalomépítés egyik terepe,

- a piaci lehetôségek a potenciális vevốk gyártási, technológiai kompetenciáitól, potenciáljától függ, így a kompatibilitás, a nehéz technikai helyettesíthetôség biztosítja a technológiai versenypozíciót,

- nagy kutatás-fejlesztési, növekvő általános beruházási, invesztíciós igények jellemzik,

- az innovációs versenyben való helytállás, sikertényezők megtalálása, innovációs kockázatok csökkentése meghatározó versenyképességi szempont, - a stratégiai szövetségek, az együttmúködési kényszerek megjelenése és személyes interakciók általi menedzselése meghatározó elemmé válik.

A business marketing megkülönböztetô jellemzóje, hogy a marketingterületek között leginkább képviseli $a$,theory-driven practice management” és a „problem-driven theory management" egységét, összhangját, az elméleti módszertan és a gyakorlati menedzsmenttudás egymást erősító kapcsolatát. A B2C és a B2B különbségeket a piaci, a termék- és a szervezeti sajátosságok, a különböző kontextusokban való eltérő személyes és szervezeti viselkedések, kapcsolatok, kötődések között találjuk. Abban többnyire marketingszakmai konszenzus van, hogy a business marketing elemzési-vizsgálati szintjei, „rétegei”, gyakorlati megjelenései a következő tevékenységek, magatartások:

- egyének, individuumok és a magatartásuk, viselkedésük (pl. beszerző, értékesítő),

- csoportok és viselkedésük (pl. Buying Center, értékesítési csapat),

- belső szervezetek és magatartásuk (pl. marketingszervezet, más releváns funkcionális szereplők),

- funkciókon átívelő és belső folyamatok, magatartások (pl. marketing mint kultúra, funkció és interakciója más cégen belüli funkcióval),

- menedzsment (pl. marketing mint specializált, intézményesített menedzsmentfolyamat),

- szervezetek közötti magatartás (pl. eladó-vevő szervezetek),

- intézményi rendszerek és a dinamikájuk (pl. piaci disztribúciós csatorna, hálózati ökoszisztémák, klaszterek múködése),
- piacok, iparágak és azok kultúrája, dinamikája (pl. megformálva a marketing és az ügyfél-magatartás által).

Az elmúlt évek szakirodalmainak többsége, mint arra utaltam is, a kapcsolatimarketing-megközelítés térnyeréséról szól, ugyanakkor mind a piaci, mind a tudományos gondolkodás fejlődése - véleményem szerint - egyértelmúen megerősíti, hogy a kapcsolatimarketing-megközelítés kereteit kiszélesítő, új dinamizáló válaszokra van szükség, melyben a különbözó iskolákat integráló elméleti alapokra épülöen, a tudásalapú gazdaság innovációs versenykényszere okán, innovációvezérelt elméleti és gyakorlati marketingmodellt kell alkotni, realizálni.

\section{A business marketing aktuális kutatási trendjei}

Egy tudomány identitását aktuális kutatási súlypontjai is formálják. A business marketing elméleti megközelítései jelentős mértékben ezekre épülő, gyakorlatszülte eredmények. A feltárt tudományos összefüggések a gyakorlat számára használható elméleteket, módszertant adnak vissza. Az elméleti, tudományos kutatások és a gyakorlatnak szóló vizsgálatok témájukban, súlypontjaikban közel állnak egymáshoz, melyek természetesen e piacokon az oktatási, tanácsadási tevékenység alapjait is jelentik. A ,jövő igényli az elózményeket, a múltat” (Marquard, 2003), azaz napjaink idôszerú trendjei az elmúlt évek kutatási irányai függvényeként jelentkeznek. LaPlaca - Katrichi (2009) átfogó elemzésükben az industrial marketing hat nagy kutatási, szakmai területét azonosították, úgymint (1) sales management, (2) beszerzési magatartás, (3) innováció, új termékfejlesztés, (4) marketingstratégiai menedzsment, (5) disztribúciós koncepció, (6) vevő-beszállító kapcsolatok. Kétségtelen, hogy a hat terület közül a vevő-beszállító kapcsolatok bírtak a legnagyobb hatással, a nyolcvanas és kilencvenes évek kapcsolati marketing mainstream-mé váló koncepciója révén, hiszen a kétoldalú kapcsolatok különböző kérdései a tágabb társadalomtudományi érdeklődés középpontjában is álltak. Az IMP-csoport a kapcsolatok és interakciók iránti érdeklődése révén (Ford, 1983; Ford - Hakansson - Johanson, 1988) késóbb a hálózati perspektíva is megjelent a beszerzési, beszállítási kapcsolatok elemzésében (Easton - Araujo, 1986). A business piacok egyre komplexebbé válnak, az ipari vevők nemcsak differenciált igényeket fogalmaznak meg, hanem egyre jobban tájékozottak is. További kihívásként jelentkeznek az elhúzódó ügyfélfolyamatok, a növekvő nemzetköziesedés, az egyre inkább valódi problémamegoldások iránti elvárás, a piacmegdolgozás növekvő adatigénye és az elektronikus kommunikáció növekvő alkalmazása az értékesítési csatornákban. A 
St.Galleni Egyetem Marketing Review folyóiratának 2013. évi negyedik száma a business marketing (Industriegütermarketing) kutatási trendjeiről kérdezett meg több vezetô kutatót. Backhaus (2013) - aki egyébként rövid távon nem számít nagy trendváltásokra - a következő tudományos kutatási súlypontokat látja:

\section{A szervezeti beszerzési magatartás-kutatások} újra megélénkülnek, melyeket a kapcsolati marketing és az árpolitikai kérdések gyakorta háttérbe szorítottak. A vizsgálandó kérdések között a Buying Center különböző szereplőinek egymást befolyásoló magatartása, a hatalmi viszonyok és a buying-center-struktúra időbeni változása válik aktuálissá.

2. A szervezeti beszerzési magatartás és a tárgyalási folyamatok integrálása is előtérben áll, ahol a domináns pszichológiai megközelítések mellett a tárgyalási konstrukciók közgazdasági tényekre alapuló továbbfejlesztése szükséges.

3. A szervezetek piacorientációjának vizsgálata egyre fontosabb, melyben a marketing szervezeti beillesztésének alternatívái is feltárásra, meghatározásra kell, hogy kerüljenek.

A gyakorlat mozgatta kutatási trendek között szintén három kiemelést látunk Backhausnál.

1. Hibrid teljesitmények, solution-marketing és az innováció kutatása - A kulcsrakész megoldások elvárása okán a tárgyi és szolgáltatáselemek egyaránt meghatározóak (performance contraction). Az innováció újra előtérbe kerül, új koncepciókkal, nemcsak az ügyfél bevonásával (open innovation), új kutatási terület megjelenésével kell számolni, ahol az innovációt egyre inkább komplex jelenségként szükséges értelmezni.

2. Big Data, az új Customer Insights trendje. Intenzív törekvések, innovatív megoldások a marketingben, az adatok előkészítése és komplex kezelése érdekében.

3. Az elillanó, változékony piacok menedzsmentje terén a fó kutatási kérdések az eladói rugalmasság biztosításáról szólnak, ahol költségszínvonal és költségstruktúra problémák is előtérbe kerülnek, ezért egyre fontosabb megtalálni a növekvő piacokat.

Backhaus szerint is a kapcsolatimarketing-alapú megközelítések, az innováció, ezen belül az újtermék-fejlesztés értékelődik fel a sikerben. Elengedhetetlennek tartja a cégek marketingfelületeinek erósítését, az ismeretek bővítését.

Christian Belz (2013) szerint a business marketing nagyon sokoldalú, eltéró piaci sajátosságokkal bír, ezért a kutatási eredményekben többnyire csalódunk, ha azokat az egész business marketingre akarjuk vonatkoztatni, hiszen a tényleges alkalmazásban mindig nagy különbségek adódhatnak, a szituációs tényezók (mint pl. termék- és piactípusok) hatásának okán. Belz kiemelt fontosságúnak ítéli az alábbi területek kutatását, elemzését:

1. a differenciált ügyfélmenedzsment: reális megoldások - minden cégnagyságra megoldások - interakciós modellek,

2. az ügyfélfolyamatok: a marketingnek és az értékesítésnek össze kell fognia a beszerzéssel,

3. az ügyfélhálózatok,

4. innovatív megoldások fejlesztése, értékesítése (solution-strategy),

5. a nemzetközi értékesítés,

6. együttmúködés a cégen belül más szervezeti egységekkel,

7. a marketing, mint kezdeményező és ösztönző szervezet múködése.

Gary Lilien összefoglaló gondolataiban, melyeket a Handbook of Business-to-Business Marketing (Lilien Greval, 2012) tartalmára, illetve egy vezetôi megkérdezés eredményeire épített, az üzleti problémák integrált kezelésének a szuikségességét emelte ki. Elhanyagoltnak ítélte az e-kereskedelem, a származtatott kereslet jelenség következményeinek, szerepének vizsgálatát és a B2G-marketing, az állami szféra felé irányuló marketinget megalapozó kutatásokat. Fontos trendnek ítélte a globális piacok fontosságát, a gyors technológiai váltások hatásait, a szervezeti változások szükségességét és a marketing stratégiai szerepének elfogadtatását. A vezetői megkérdezés alapján az innováció és a marketing kapcsolatának megalapozását és a szervezeti beszerzési magatartás vizsgálatát emelte ki.

A nevesített kutatási trendek irányai sokrétúnek tûnnek, de jelzik annak igényét, hogy egy integrált, az egyes meghatározó tényezők, tevékenységek közötti összefüggések feltárására, a vállalkozások versenyképességét, sikerét biztosító folyamatok, s azok érvényesítési stratégiájának a feltárására kell koncentrálni. Ebben a piacorientáció, a beszerzési magatartás, a Big Data, az új Customer Insights, a cégen belüli együttmúködések, az ügyfélkapcsolat-menedzsment, a nemzetközi értékesítés és az innovációkra épülő integrált problémamegoldás feladatának való megfelelést kell megalapozni.

\section{Az innovációvezérelt businessmarketing- menedzsment modellje}

A kutatási súlypontok, s eredményeik megerősítik, hogy a nagy versenyintenzitású és egyre inkább globalizálódó piacokon, csak a tudásintenzív termékek, a 
kreatív piaci megoldások és a hatékonyan (rugalmasan, kooperatívan) múködó vállalati szervezetek képesek a vállalkozások sikerét biztosítani (Cooper - Edgett, 2009; Loock - Steppeler, 2010). Az innovációs versenyelónyök, a Competitive Innovation Advantage (CIA) építése, realizálása képezik a sikeres piaci pozíció elérésének, megôrzésének alapját. Már nem elegendő a vállalkozásoknak csak a termékfejlesztésbe innoválniuk, hanem egy innovációs portfólióban kell gondolkodniuk. Nem véletlenül ír Noé (2013) Innováció 2.0-ról, s csatlakozik azokhoz, akik azt egy új, a négy üzleti innovációtípus (termék, folyamat, szervezet és marketing) mellett a társadalmi innovációkat is integráló hatékony innovációportfólióra épülö korszaknak tekintik. Mikor, milyen típusú innovációra van szüksége egy vállalkozásnak? Mi biztosítja, hogy az innovációra fordított erőforrások tényleg vállalati versenyképességet teremtenek, s piaci sikert hoznak? Hogyan csökkenthetók a technológiai és piaci kockázatok? Ezek a „klasszikus kérdések” ugyanakkor ma új válaszokat igényelnek. Az innovációs tevékenység, mint a piaci lehetöségekre, veszélyekre, azaz az innovációs (elözetesen megteremtett vagy utólagos kielégített) igényekre és kényszerekre adott válasz értelmezhető. Ez a szélesre nyitott definíció azt erősíti, hogy az innovációs tevékenység nem egy eseti, egyszeri plusz a vállalkozásoknál, hanem a mindenkori versenyképességet biztositó komplex, folyamatos, s integratív feladat. A marketing a vállalkozások üzleti sikerét, céljai elérését támogató alapvető feladatának egyre inkább csak úgy tud megfelelni, ha ô is az innovációs tevékenységre összpontosít, „innovációmarketingként” múködik, azaz a vállalkozás innovációs versenyelőnyeinek kialakítását és azok piaci megvalósítását segíti. Az innovációmarketing lényege a jelenlegi és jövőbeni piacokra irányuló új teljesítménykínálat, illetve potenciál kialakítása és értékesítése (Trommsdorf - Steinhoff, 2007, p. 43.). Az innovációmarketing - a különbözó szervezeti egységekkel együttmúködó, innovációs tevékenységek belsó és külsố integrálását végzó - értékteremtó, önmaga is innovációt képezó (marketinginnováció) tevékenység. A piacorientáció elveire épüló sokoldalú marketingmenedzsment aktivitással támogatja a vállalkozás eróforrásainak, kompetenciáinak, különbözó folyamatainak és teljesítményprogramjainak kialakitását, innovációs versenyelönnyé formálását, valamint annak piaci értékesitését, realizálását. Az innovációmarketing szerepe átfogó, a teljes értékteremtó folyamatot végig kíséró, melyben a menedzsment stratégiai innovációs döntéseinek az információs, piackutatási támogatása, az erőforrás-felhasználás optimalizálásának segítése, az innovációs fejlesztési folyamat támogatása, a piaci lépések stratégiáinak, a piacbevezetés idôzítése, a pozicionálás, a kommunikációtervezés, a kooperációs stra- tégia kialakítása egyaránt hozzá tartozik. Az innováció marketingvezéreltté kell, hogy váljon!

A marketing feladata az egyre inkább az innováción nyugvó vállalati versenyképesség, piaci siker biztositása, s így a business marketing lényegi eleme, szemlélete. A marketing innovációs folyamatokon belüli felértékelődése több fázison ment át (Schewe - Becker, 2009), ahol annak első (többek által zéró generációnak nevezett) szakaszát a technology-push vagy market-pull kérdések jellemezték, míg a második szakasz az ötletelfogadási és ötletgenerálási modelleken nyugodott. A harmadik szakasz (az innovációmarketing második nemzedéke) a technikai fejlesztés és a marketingkoncepció párhuzamosságának felismeréséról szólt (Loock - Steppeler, 2010, p. 24.). Véleményem szerint, az innováció és a marketing szerves összekapcsolását jelentő, fontosságában felértékelődő, jelenlegi, 3. generációs elméleti megközelítést, az innovációs teljesítmény versenyképességét, piaci sikerességét biztosítani hivatott gyakorlatot a marketingvezérelt innováció korszakának tekinthetjük, ahol maga a marketing is innovatívvá, innovációvezéreltté válik. Az ezt vizsgáló több éves, empirikus vizsgálatokkal is támogatott kutatásaim eredményei közül öt - a formálódó menedzsmentmodell múködését magyarázó, igazoló - megállapítást, tételt emelek ki:

1. A kívánatos, hatékony innovációportfólió hazai vállalati gyakorlata jellemzóen féloldalas, a szervezeti és marketinginnovációk tudatos integrálása hiányos.

2. Az innovációs tevékenységet megalapozó és hatásait tudatosan értékelő vállalati stratégiai innovációs piackutatások és az innovációkontrolling-elemzések elengedhetetlen sikertényezók, de mind az intenzitásuk, mind a módszertanuk vonatkozásában a hazai vállalkozások marketingjének gyenge pontját képezik (Piskóti, 2014b).

3. Az innovációk eredményességét és sikerét $a$ vállalkozások stratégiai kompetenciái, eröforrásai, valamint a folyamat- és a terméktényezóinek elönyei, azok összhangja, integráltsága határozza meg. A vizsgált magyar vállalkozások mintáján a terméktényezók, elónyök mutatják a legerósebb sikerkapcsolatot, míg az elözó két tényezókör közvetlen korrelációja gyengébb, elsốsorban a termékjellemzókön át érvényesülnek (Piskóti Nagy - Molnár, 2013).

4. Egyre inkább erősödő trend az innovációk nyitottabbá tétele, a kooperatív, hálózati és klaszter együttmúködésekre, kapcsolatmenedzsmentre épülő nyílt innovációk (Baaken, 2009; Arnold - Zerwas - Kortzfleisch, 2014; Davey - Plewa - Muros, 2014; Csizmadia - Grosz, 2012; Ha- 
kansson, 2010). Ritter - Gemünden (2010) megközelítésére építve igazoltam, hogy a hálózati és technológiai kompetencia egymást erösítóen, erösen korrelál az innovációs sikerrel. A hazai vizsgálatok csak egy ,félig nyílt” (az ügyfél és beszállitói kapcsolatokra fókuszáló) innovációs gyakorlatot mutatnak, nem integrált megoldásokat jeleznek a lehetséges többi szerepló, köztük a felsóoktatással sem (Piskóti - Nagy - Molnár, 2013).

5. A marketingképességek, a hatékony marketingfolyamatok elengedhetetlen tényezői, meghatározói az innovációs sikernek, az innovációs versenyelőnyök kiépítésének, miként azt az előző modell-leírásban marketingvezérelt innováció és innovációvezérelt marketinggondolatokkal érzékeltettem.

Ennek bizonyítását empirikus kutatással - a Nemzeti Innovációs Hivatal, a B.A.Z. megyei Kereskedelmi és Iparkamara, valamint a Magyarok a Piacon Klub támogatásával - 2014 november-decemberében lebonyolított megkérdezéssel végeztem. A 86 céget tartalmazó minta megbízhatósági szintje 95 százalék, pontossági szintje pedig $\pm 10,6 \%$. A mintába a domináns ipari (42\%), szolgáltató $(28 \%)$ cégek mellett mezőgazdasági vállalkozások is bekerültek. Nagyvállalat $12 \%$-ban, középvállalkozás 49, míg kisvállalkozás 39\%-ban töltötte ki a kérdóívet. Döntően hazai tulajdonú cégek válaszoltak, csak 16\%-nál volt külföldi érdekeltség. A válaszadók 70\%-a számolt be az elmúlt években növekedésrôl, $23 \%$ változatlan, míg $7 \%$ csökkenő bevételekről. 80\%-uknál meghaladta az éves árbevétel az egymilliárd forintot. Weerawardena (2011) négy-tényezócsoportos modelljéból indultam ki:

1. a vállalkozói, vállaltvezetôi szemlélet, magatartás (EI), melyet a K+F kiadások, új termékek, szolgáltatások preferálása, versenytárshoz való viszony, piaci gyorsaság, kockázatvállalás, merészség, külső forrásbevonás kérdésekkel ragadtam meg,

2. a marketingképességek és -aktivitások (MC) mérését, a versenytársakkal történő összehasonlítást tartalmazóan az ügyfélszolgálat, értékesítés, disztribúció szélessége, promóció, kommunikáció, kutatások, termékdifferenciálás, piacbevezetés, külső szolgáltatók igénybe vétele kategóriákkal végeztem,

3. a harmadik tényező különböző innovációtípus aktivitása és intenzitása (OII) volt, ahol a termék-, folyamat-, szervezeti és marketinginnovációk alkalmazásának intenzitására, újszerűségére egyaránt kitértem,

4. míg a fenntartható, innovációkra épülő versenyelőnyöket (SCA) szintén a versenytársakkal való összehasonlításban az alábbi tényezókkel ragadtam meg: új piacokra lépés, piacrészesedés, elégedettség, nyereség elérésével, valamint a cég teljesítményének más jellemzőivel, mint innovációtípusok színvonala, tanulási, reagálási képesség, kapcsolati-hálózati képesség, marketingképességek versenytársakkal való összehasonlításával.

A hazai mintán történt modelladaptációs szándék nem teljesen ugyanazokat az eredményeket hozta, mint Ausztráliában. Hasonlóan Weerawardenahoz sikerült igazolni

- a marketingképességek (MC) és az innovációs intenzitás (OII),

- a marketingképességek (MC) és a fenntartható versenyelőny (SCA) kialakítása,

- az innovációs intenzitás (OII) és a fenntartható versenyelőnyök (SCA), valamint

- a vezetői magatartás (EI) és a fenntartható versenyelőnyök (SCA) közötti szignifikáns kapcsolatot.

A marketingképességek, innovatív aktivitások egyre jobban támogatják az innovációs tevékenység sikerét. A vezetői magatartás és a marketingképességek közötti kapcsolatot, Weerawardenanál múködő összefüggését nem tudtam megerósíteni, s gyenge a marketing és a versenyelőnyök közvetlen kapcsolata is. Az alábbi modelleredményeket kaptam:

\begin{tabular}{|l|l|l|l|l|l|l|l|l|}
\hline & & $\begin{array}{l}\text { Esti- } \\
\text { mate }\end{array}$ & S.E. & C.R. & P & $\begin{array}{c}\text { La- } \\
\text { bel }\end{array}$ & $\begin{array}{c}\text { Esti- } \\
\text { mate }\end{array}$ \\
\hline $\begin{array}{l}\text { O I I_ } \\
\text { fact }\end{array}$ & $<--$ & MC_fact &, 591 &, 166 & 3,572 & $* * *$ & &, 540 \\
\hline $\begin{array}{l}\text { SCA_ } \\
\text { fact }\end{array}$ & $<---$ & OII_fact &, 258 &, 115 & 2,249 &, 025 & &, 344 \\
\hline $\begin{array}{l}\text { SCA_ } \\
\text { fact }\end{array}$ & $<--$ & EI_fact &, 464 &, 186 & 2,490 &, 013 & &, 381 \\
\hline
\end{tabular}

A kutatási eredmények egyértelmúen megerősítették a tanulmányom elején megfogalmazott összefüggéseket, az innovációs tevékenység fenntartható versenyelónyök kialakítására gyakorolt hatását, ahol az innovációintenzitást jelentős mértékben a marketingképességek befolyásolják. A marketingképességek részben a versenyelőnyöket, kisebb erősséggel ugyan közvetlenül is meghatározzák, s maguk innovációs típust is képezve, ugyanakkor AMOS-modellbe illesztése lerontja OII és SCA kapcsolatát. (2. ábra)

A vállalkozói, vezetôi magatartás stratégiai döntései meghatározóan hatnak fenntartható versenyelőnyre. A cégvezetés és a marketingképességek közötti nem megerősített kapcsolat részben vezetői magatartás következetlenségét, illetve a marketing nem mindig megfelelő vállalkozáson belüli, szervezeti megjelenését, pozíció- 
2. ábra

Az innovációs együttmúködések veszélyei, érzékelt kockázatai funkcionalitás szerint

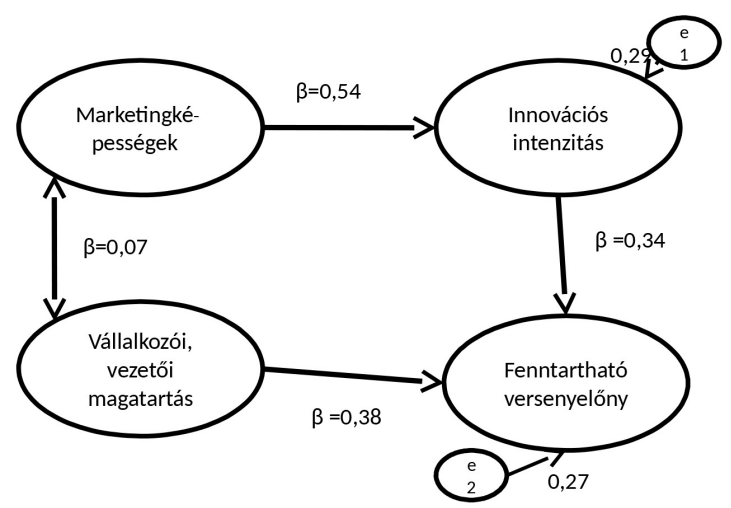

Forrás: saját szerkesztés a 2014-es kutatás alapján

ját mutatja. A vezetői magatartás és az innovációs aktivitás erôs kapcsolatának hiánya láthatóan a még jelentős mértékben termékinnovációs, avagy legfeljebb még gyártási, múszaki jellegú innovációk prioritásának a fennmaradását, a hiányzó teljes innovációportfólióban gondolkodás gyengeségeit jelzi.

\section{Összegzés}

A tanulmány alapvető célja nem csupán a business marketing tudományos érettségének, szakmai-gyakorlati szerepének, helyének bemutatása volt, hanem annak bizonyítása is, hogy a business marketing sajátosságaira épülő marketinggondolkodás a vállalkozások versenyképességére, sikerességére - az innováció és a marketing egymást inspiráló, vezérlő dinamikus kapcsolata révén - alapvető hatással bír, s megszívlelendő nemcsak business piaci terepeken is.

\section{Felhasznált irodalom}

Alderson, W. (1965): Dynamic marketing behavior: A functionalist theory of marketing -Homewood, Illinois: Irwin

Baaken, T.(2009): Science-to-Business Marketing und Partnering als konsequente Weiterentwicklung des Technologietransfers. in: Merten, W. (Hrsg.): Wissenschaftsmarketing - Dialoge gestalten. Bonn: S. 41-54.

Backhaus, K. (1997): Industriegütermarketing. München: Vahlen Verlag

Backhaus, K. - Voeth, M. (2004): Handbuch Industriegütermarketing. Wiesbaden: Gabler Verlag

Backhaus, K. - Belz, C. - Lilien, G. (2013): Trends im Industriegütermarketing - Fortschritte, Entwicklungen und zukünftiger Forschungsbedarf. Marketing Review St. Gallen, 4.: p. 10-25.
Belz, C. - Schögel, M. - Tomczak, T. (2007): Innovation Driven Marketing. Wiesbaden: Gabler, Thexis

Cooper, R. G. - Edgett, S. (2009): Successful Product Innovation: A Collection of Our Best. Product Development Institute Inc., www.stage-gate.com

Csizmadia, Z. - Grosz, A. (2012): Innováció és együttmúködési hálózatok Magyarországon. in: Bajnóczy - Lengyel - Málovics (szerk.): Regionális innovációs képesség, versenyképesség és fenntarthatóság. Szeged: JATEPress: p. 52-73.

Davey, T. - Plewa, C. - Muros, V. G. (2014): University-Business Cooperation Outcomes and Impacts A European Perspective. in: Kliewe-Kestint (Hrsg.): Moderne Konzepte des organisationalen Marketing. Wiesbaden: Springer Fachmedien: p. 161-172.

Easton, G. (1998): Case research as a methodology for industrial marketing. in: Naude - Turnbull (ed.): Network dynamics in international marketing. London: Pergamon Press London

Ford, D. (2003): Business marketing. Budapest: KJKKerszöv

Grönroos, C. (1990): Relationship Approach to Marketing in Service Contexts: The Marketing and Organizational Behavior Interface. Journal of Business Research, 1: p. 3-11.

Hadjikhani, A. - LaPlaca, P. (2013): Development of B2B marketing theory - Industrial marketing management: Multidisciplinary perspectives. Industrial Marketing Management, 42.: p. 294-305.

Hakansson, H. (2010): Határtalan hálózatok. Budapest: Alinea Kiadó

Henard, D. H. - Szymanski, D. M. (2001): Why Some New Products Are More Successful Than Others. Journal of Marketing Research, Vol. XXXVIII: p. 362-375

Hetesi, E. - Veres, Z. (2004): An empirical investigation on loyalty - The case of packaging industry. in: IMP Proceedings, Copenhagen

Hetesi E. - Vilmányi, M. (2012): A dinamikus kapcsolati képességek és a lojalitás szerepe a szervezetközi kapcsolatokban. Competitio, 11.: (2.): p. 76-93.

Hunt, S. D. (2013): A general theory of business marketing: R-A theory, Alderson, the ISBM framework, and the IMP theoretical structure. Industrial Marketing Management, 42.: p. 283-293.

Loock, H. - Steppeler, H. (2010): Marktorientierte Problemlösungen im Innovationsmarketing. Wiesbaden: Gabler Verlag

Mandják, T. (2005): Marketing-szemléletmód és üzleti kapcsolatok. Vezetéstudomány, 5. sz.: p. 14-24.

Meffert, H. (2007): General Marketing oder sektorale Spezialisierung - Was können Industrie- und Konsumgütermarketing voneinander lernen. in: Büschken, J. - Voeth, M. - Weiber, R. (2007): Innova- 
tionen für das Industriegütermarketing. Stuttgart: Schäffer-Poeschel Verlag: p. 109-144.

Möller, K. (2013): Theory map of business marketing: Relationships and networks perspectives. Industrial Marketing Management, 42.: p. 324-335.

Möller, K. - Menninger, J. - Robers, D. (2011): Innovationscontrolling: Erfolgreiche Steuerung und Bewertung von Innovationen. Stuttgart: SchäfferPoeschel Verlag

Noé, M. (2013): Innovation 2.0. Unternehmenserfolg durch intelligentes und effizientes Innovieren. Wiesbaden: Springer Gabler Verlag

Peters, L. - Pressey, A. D. - Vanharanta, M. - Johnston, W. J. (2013): Theoretical developments. Industrial Marketing Management, 42.: p. 273-282.

Piskóti I. (2007): Innovációmarketing-marketinginnováció. Miskolc: Miskolci Egyetem

Piskóti, I. (2012): The Social Problem Sensitivity of the Hungarian Population and Their Social Marketing Sensitivity. Theory Methodology Practice, 8: (1): p. 59-67.

Piskóti, I. - Nagy, Sz. - Molnár, L. (2013): Innováció piaci sikere - A hazai gyakorlat empirikus modellje. Tér-Gazdaság-Ember, 1: (1): p. 85-102.

Piskóti, I. (2014): Business marketingmenedzsment üzleti döntések marketingtámogatása. Budapest: Akadémiai Kiadó

Piskóti, I. (2014a): Az innovációvezérelt marketing trendjei. in: Piskóti, I. (szerk.)(2014): Marketingkaleidoszkóp 2014 - Innovációvezérelt marketing. Miskolc: Miskolci Egyetem Marketing Intézet: p. 10-21.

Piskóti, I. (2014b): Az innovációmarketing integrált modellje. in: Piskóti, I. (szerk.)(2014): Marketingkaleidoszkóp 2014 - Innovációvezérelt marketing. Miskolc: Miskolci Egyetem Marketing Intézet: p. 43-58.

Ritter, T. - Gemünden, H-G. (2003): Network competence: Its impact on innovation success and its ante- cedents. Journal of Business Research Volume, 56, Issue 9, September: p. 745-755.

Schewe, G. - Becker, S. (2009): Innovationen für den Mittelstand - Erfolgreiche Innovationen auf Basis theoretischer Modelle. Wiesbaden: Gabler Verlag

Sheth, J. N. - Garrett, D. (1986): Marketing Theory: Classic and contemporary reading. Cincinnati: South-Western Publishing Co.

Sheth, J. N. - Parvatiyar, A. (1995): The evolution of relationship marketing. International Business Review, 4/4.: p. 397-418.

Thiebes, F. - Plankert, N. (2010): Chanchen und Risiken zwischenbetrieblicher Innovationskooperationen. in: Loock - Steppeler (Hrsg.): Marktorientierte Problemlösungen im Innovationsmarketing. Wiesbaden: Gabler Verlag: p. 71-94.

Trommsdorff, V. - Steinhoff, F. (2007): Innovationsmarketing. München: Vahlen

Yang, Z. - Su, C. (2014): Institutional theory in business marketing: A conceptual framework and future directions. Industrial Marketing Management, 43.: p. 721-729.

Vargo, S. - Lusch, R. (2011): It's all B2B, and beyond - Toward a system perspective of the market. Industrial Marketing Management, 40.: p. 181-187.

Vágási, M. (2006): Az innováció alapkoncepciói és az innovációmarketing tárgya. in: Vágási - Piskóti Búzás (2006): Innovációmarketing. Budapest: Akadémiai Kiadó: p. 17-54.

Veres, Z. (2009): Competence-Based Risk Perception in the Project Business. Journal of Business and Industrial Marketing, Vol. 24, Issue 3/4: p. 237-244.

Weerawardena, J. (2003): The role of marketing capability in innovation-based competitive strategy. Journal of Strategic Marketing, 11:1: p. 15-35.

Wilkie, W. - Moore, E. (2003): Scholarly research in marketing. Exploring the four areas of thought development. Journal of Public Policy + Marketing, 22.: p. 116-146. 